
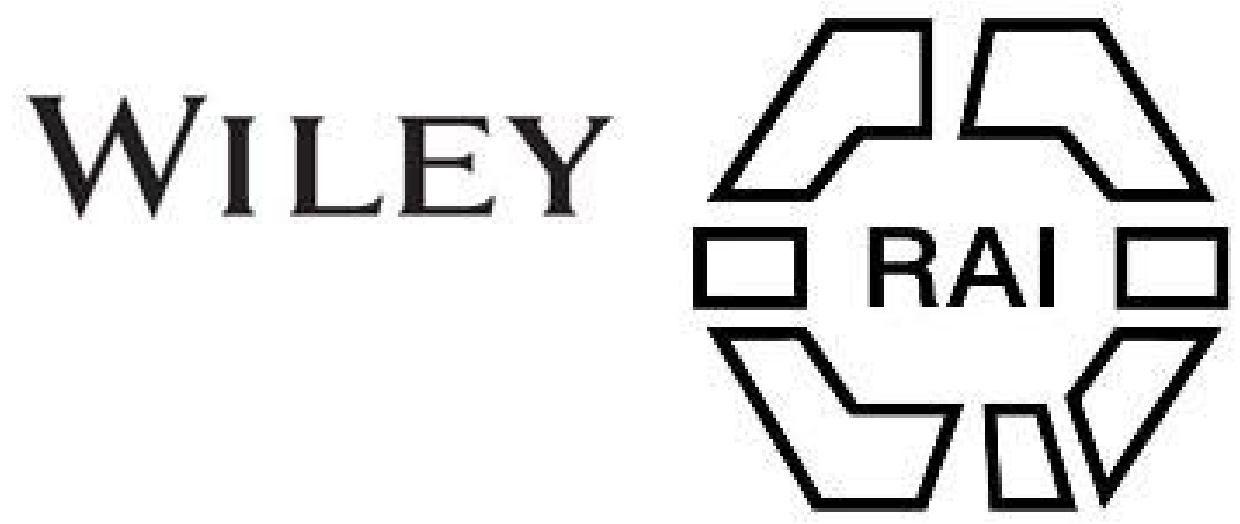

\title{
69. Note on Bronzes in Persia.
}

\section{Author(s): R. Burn}

Source: Man, Vol. 3 (1903), pp. 120-121

Published by: Royal Anthropological Institute of Great Britain and Ireland

Stable URL: http://www.jstor.org/stable/2839828

Accessed: 24-06-2016 21:59 UTC

Your use of the JSTOR archive indicates your acceptance of the Terms \& Conditions of Use, available at

http://about.jstor.org/terms

JSTOR is a not-for-profit service that helps scholars, researchers, and students discover, use, and build upon a wide range of content in a trusted digital archive. We use information technology and tools to increase productivity and facilitate new forms of scholarship. For more information about JSTOR, please contact support@jstor.org.

Wiley, Royal Anthropological Institute of Great Britain and Ireland are collaborating with JSTOR to digitize, preserve and extend access to Man 
worn at the edges and perhaps used as a strike-light; five iron nails and another small bit of iron, a flat stone five by four and three quarter inches with a circular hole one and three-eighth inches in diameter and half an inch deep sunk into it as if for a mould, and three small pieces of glass.

As upwards of fifty fragments of burnt bone and several flat slabs of freestone were found in a short. cut twelve feet long and five feet wide, it is probable that a burnt interment had been disturbed by the constructors of the earthwork. Nothing, however, was found that could define its exact age or exactly determine its purpose.

The next site explored is in a fenced enclosure marked on the Ordnance map as "Prætorium," though locally known as the Camp. It lies on low ground about eleven hundred yards east of the Black Hill and one hundred and eighty yards west of the Isla. Roughly speaking, the work is quadrangular with faces of unequal length, that to the S.W. having a considerable outward bulge. Formerly it eonsisted of four ramparts and four ditches, but now the outer ditch has been taken into the field in which the enclosure stands. The inner rampart forms an irregular pentagon, the longest side of which is seventy feet and the shortest thirty-four feet. At present the ramparts are hardly two feet, the outer one only one foot two inches, above the natural surface. From crest to crest measures twenty feet, except for the fourth or outer one, which is only fifteen feet from the third rampart. The ditches originally were about three feet deep, though now much silted up. There are three well-defined entrances from the N., the S., and the S.E., with slight indications that one formerly existed from the N.W., all converging to the centre.

In the centre of the pentagon is a low mound, forty-eight feet in diameter and two and a half feet high, which has the appearance of being sepulchral. A trench, six feet wide, cut across the centre from S.E. to N.W., the output of wbich was carefully riddled, gave no evidence of an interment. At the centre the excavation was increased to include an area of fourteen by twelve feet and carried down below the undisturbed gravel without finding anything of importance. But later on, in carrying a trench along the southern roadway towards the centre of the mound, a burnt interment was discovered and subsequently two others, all on the south side of the trench through the centre. All three were on the natural level about one foot two inches below the surface. The scanty burnt remains had been placed at the foot of one or more flat slabs in a line, set on end in the underlying gravel. When first noticed the slabs had the appearance of being the sides of a cist, but in each case it proved that there was no cist and the upright line of slabs was a sufficient protection. A thin layer of large gravel surrounded each interment. There were no urns. The only object found with one interment was a globule of vitreous paste, about the size of a pea, with a thorn-like process projecting from it. Oné reason why so few burnt remains were brought to light must be attributed to the rabbits, as the mound, and, indeed, the whole enclosure, is a regular rabbit warren.

Nothing, unfortunately, was discovered to throw any light on the exact age of either the interments or of the earthworks, or whether the two were contemporary. Probably the interment is somewhat later, as I know of no example of a round barrow surrounded by a pentagonal and a quadrangular vallum. As the site of the "Camp" is surrounded at no great distance by higher ground it was not well adapted for a fortified post.

JOHN ABERCROMBY.

Persia. Burn.

Note on Bronzes in Persia. Being an Extract from a Letter by R. Burn, 69
S.S., communicated by the Secretary.

An account of an archaic bronze tripod from Southeru Persia is given in MAN, 1903. 20. In 1894 I stayed a night at Dih-i-Diz where this tripod was discovered, and when I asked the villagers if they had any coins, they produced three bronzes, one 
apparently an Apollo, another a Hercules (each. being about eighteen inches long), and a greybound about six inches long. Mr..Seddon, I.C.S., who was with me, agreed that the execution was good, but we had recently: seen forged coins, and were not inclined to pay the high price asked by the villagers. At that time $I$ had seen no account of bronzes from Persia, but, in view of Major Sylke's discoveries, it seems possible these were genuine. We both thought the style was distinctly Greek.

May I point out that Dih-i.Diz is not between Malamir and Gudar Balutak. The last place is between the other two.

R. BURN.

Totemism.

REVIEWS.

Social Origins. By Andrew Lang, M.A., LL.D. Primal Law. By J.'T. 70
Linson. Londor : Longmans. $1903.23 \times 15 \mathrm{~cm} . \quad$ Pp. $x$ xiii +311. Price $10 s .6 d$. net.

In this volume two authors put before us a theory of the origin of totemism, exogamy, and the laws of avoidance. If there is any advantage in adhering to chronological order Mr. Atkinson's share of this work, beginning, as it does, with man in the brutal stage, might perhaps have occupied the first place, leaving Mr. Lang's review of the problems of tribal organisation and totemism; which demand a longer course of human evolution, to bring up the rear.

Mr. Atkinson's solution of the origin of exogamy is, briefly stated, sexual jealousy. He conceives the course of events to have been as follows: Observation shows that among the higher mammals and some birds the small groups into which they are divided contain but one adult male; the remainder, the progeny of the leader of the herd, hover in many cases on its outskirts until such time as their paternal enemy, his natural force abated, falls a victim to their combined attack; the division of the spoil results in the setting up of a number of similar groups, each with a single adult male. This Mr. Atkinson supposes to have been the condition of homo alalus also. In course of time, however, he conjectures, maternal love, accentuated by the more prolonged infancy which probably accompanied a certain increase in the intellectual powers, succeeded in saving from banishment one of her male offspring on condition that he claimed no marital rights over the females of the horde. The increased power of the group both in offence and defence would tend to perpetuate this innovation, the more so as the marital rights might, at the death of the patriarch, descend without conflict to the other adult male member of the horde. The inclusion of a young adult male or males on the understanding that the rights of the father were respected led, firstly, to the evolution of the primal law of brother and sister avoidance as a duty, and secondly, to the introduction of exogamy. The females brought from without by the younger males were distinguished from those born in the horde, and in this explicit distinction lay the root of all future progress.

Mr. Atkinson goes on to trace the development of the various avoidances-father and daughter-in-law, mother and son-in-law, \&c.-in accordance with his theory, and shows how unsatisfactory the theory of hostility, due to resentment of capture, is as an explanation of the facts. His final chapter on the classificatory system displays him, singularly enough, as a defender of the theory of group marriage, a position hard to reconcile with his thesis of the influence of jealousy in the evolution of social institutions. But it must be remembered that the work is posthumous.

It is clear that we have but few data on which to go in attempting to estimate the value of this ingenions theory. Our knowledge of the habits of the higher apes is far from being complete, and even were it otherwise the history of the anthropoids could not carry us very far along the path of human progress. On the whole it may be said that it gives a better account of the facts as to avoidauce than the theories of either 